\title{
Pengaruh Book Tax Differences, Arus Kas Operasi, Tingkat Hutang, Volatilitas Penjualan Dan Kepemilikan Institusional Terhadap Persistensi Laba
}

\author{
Suhayati ${ }^{1}$, Dirvi Surya Abbas ${ }^{2}$, Mohamad Zulman Hakim ${ }^{3}$ \\ Universitas Muhammadiyah Tangerang ${ }^{1,2,3}$ \\ Email korespondensi: suhayati506@gmail.com
}

\begin{abstract}
Abstrak: Tujuan penelitian adalah untuk mengetahui pengaruh dari book tax differences, arus kas operasi, tingkat hutang, volatilitas penjualan dan kepemilikan institusional terhadap persistensi laba pada perusahaan Sektor property, real estate and building yang terdaftar di Bursa Efek Indonesia, khususnya pada tahun 2013-2018 sebagai populasi penelitian. Periode waktu penelitian yang digunakan adalah 6 tahun yaitu periode 2013-2018. Metode pengambilan sampel yang digunakan adalah purposive sampling dengan total sampel sebanyak 7 perusahaan sector property, real estate and building. Data yang digunakan dalam penelitian ini merupakan data sekunder yang berasal dari Buirsa Efek Indonesia (BEI). Pengolahan data dilakukan dengan Eviews 10.0. Hasil penelitian menunjukkan bahwa book tax differences (BTD) memiliki pengaruh negative terhadap persistensi laba dan kepemilikan Institusional memiliki pengaruh positif terhadap persistensi laba. Sedangkan tingkat hutang, arus kas operasi dan volatilitas penjualan tidak memiliki pengaruh terhadap persistensi laba.
\end{abstract}

Kata Kunci : Book Tax Differences, Arus Kas Operasi, Tingkat Hutang, Volatilitas penjualan, Kepemilikan Institusional, Persistensi Laba

Teori akuntansi positif menggunakan kemampuan pemahaman dan pengetahuan akuntansi serta penggunaan kebijakan akuntansi yang paling sinkron agar dapat menjelaskan sebuah proses untuk menghadapi kondisi tertentu di masa mendatang. Teori akuntansi positif pada dasarnya memiliki tujuan misalnya untuk menjelaskan dan memprediksi praktikpraktik akuntansi. (Kritik et al., 2016)

Laporan keuangan berfungsi untuk menginformasikan kondisi keuangan dan hasil usaha perusahaan yang diaplikasikan oleh para pemakainya sesuai dengan keputusan masing - masing informasi akuntansi disajikan dalam laporan keuangan (Cavenett, 2013). Adapun pengertian laporan keuangan menurut (SAK, 2015) menyatakan bahwa laporan keuangan merupakan bagian dari proses laporan keuangan, yang lengkap terdiri dari neraca, laporan rugi laba, laporan perubahan perubahan ekuitas dan juga catatan serta laporan lain sebagai penjelasan bagian integral dari laporan keuangan, tujuan laporan keuangan adalah menyediakan informasi yang berhubungan dengan posisi keuangan kinerja serta perubahan posisi keuangan suatu perusahaan agar bermanfaat bagi sejumlah pemakai untuk pengambilan keputusan.

Menurut penelitian yang dilakukan oleh (Penman 2001) dalam (Persada \& Martani, 2010) menyatakan bahwa laba akuntansi merupakan harapan di masa mendatang (expected future earnings) yang tercermin pada laba tahun berjalan (current earnings) merupakan pengertian dari persistensi laba. Persistensi laba sering digunakan untuk pertimbangan 
laba yang berkualitas karena persistensi laba adalah komponen dari karakteristik kualitatif relevansi yaitu predictive value yang dicetuskan oleh (Jonas dan Blanchet 2000) dalam (Persada \& Martani, 2010). Salah satu pengukuran untuk memprediksi laba dimasa mendatang adalah persistensi laba. Laba yang persisten adalah laba yang tidak mengalami masalah baik sedikit ataupun banyak, hal ini dapat menggambarkan kinerja keuangan yang sebenarnya dan merefleksikan keberlanjutan laba dimasa mendatang, oleh (Wijayanti, 2006) dalam (Gusnita \& Taqwa, 2019). Sedangkan Definisi persistensi laba menurut Fanani (2010) dalam penelitian (Rahmadhani et al., 2016) yaitu suatu ukuran yang menjelaskan kemampuan perusahaan untuk mempertahankan jumlah laba yang diperoleh saat ini sampai masa mendatang. Laba merupakan salah satu komponen yang menarik bagi pengguna laporan keuangan, maka laba perlu diperhatikan oleh calon investor potensial bukanlah laba yang tinggi, namun juga laba yang persisten. Laba adalah bagian yang penting untuk perusahaan, karena laba merupakan bahan laporan keuangan yang berfungsi untuk pengambilan keputusan suatu perusahaan. Melalui laba ini dapat dikatakan baik atau tidaknya dalam hal ini yang membuat laba menjadi perhatian penting bagi stakeholder untuk mencerminkan kondisi perusahaan yang baik. (Septavita, 2016)

Pada tahun 2018 kuartal III, ada salah satu perusahaan yang mengalami anjloknya kinerja seperti PT Agung Podomoro Land Tbk (APLN). Laba bersih dan penjualan perusahaan mengalami penurunan yang signifikan dari tahun sebelumnya, karena tahun sebelumnya menghasilkan laba yang lebih tinggi. PT Agung Podomoro Land Tbk (APLN) pada saat itu mengalami penurunan sejumlah $30,3 \%$ dibandingkan dengan tahun sebelumnya. (industri.kontan.co.id)

Seperti hal-hal nya perusahaan lain yang mengalami kerugian pada tahun-tahun sebelumnya seperti perusahaan Fortune Mate Indonesia Tbk (FMII), Eureka Prima Jakarta Tbk (LCGP), City Retail Developments Tbk (NIRO), Ristia Bintang Mahkota Sejati (RMBS).

Menurut (Purba dan Andreas, 2005) dalam (Rahmadhani et al., 2016) Book-tax differences dapat mempengaruhi persistensi laba karena adanya perbedaan perhitungan laba menurut Standar Akuntansi dan Ketentuan Perpajakan akan menimbulkan selesih yang mampu menambah atau mengurangi laba di masa depan.

Menurut Wardana dan Martani (2014) dalam penelitian (Rahmadhani et al., 2016) menyatakan bahwa Book-tax differences adalah perbedaan laba akuntansi dan laba fiskal yang terjadi karena perbedaan antara peraturan perpajakan dengan peraturan dalam hal pengakuan pendapatan dan laba. Menurut penelitian Zain (2008) dalam Lestari (2011) dalam (Rahmadhani et al., 2016) mencetuskan bahwa book tax differences disebabkan oleh perbedaan tujuan serta dasar hukumnya, tahun pajak atau tahun buku, metode akuntansi yang digunakan dan konsep yang menjadi rujukannya, walaupun dalam beberapa hal terdapat persamaan antara akuntansi pajak yang mengacu pada ketentuan 
peraturan perundang - undangan perpajakan dan akuntansi keuangan yang mengacu kepada standar akuntansi keuangan. Perbedaan dasar kedua penyusunan laporan keuangan menyebabkan perbedaan penghitungan laba (rugi) suatu perusahaan yang menimbulkan total laba yang berbeda antara laba akuntansi dengan laba fiskal atau yang dikenal dengan istilah book-tax differences.

Menurut penelitian yang dilakukan oleh (Annisa \& Kurniasih, 2017) mengenai book tax differences menunjukkan bahwa adanya perbedaan laba akuntansi dengan laba fiskal yang berpengaruh bernilai positif signifikan terhadap persistensi laba. Menurut penelitian (Asma, 2013) Perbedaan laba akuntansi dengan laba fiskal berpengaruh signifikan negatif terhadap persistensi laba. Hal ini sama juga dengan hasil penelitian yang dilakukan oleh (Zdulhiyanov, 2015) hasilnya menunjukkan terdapat pengaruh negatif signifikan sama perusahaan dengan large positive (negative) book tax difference terhadap persistensi laba. Perusahaan bersama large positive (negative) book tax difference memiliki persistensi laba lebih rendah daripada dengan perusahaan yang memiliki small book tax difference. Berbeda hal dengan penelitian (Hidayat \& Fauziyah, 2019) yang menyatakan bahwa Book Tax Differences tidak berpengaruh terhadap persistensi laba.

Menurut (Sulastri, 2014) tingkat hutang atau sering juga disebut dengan tingkat solvabilitas adalah kemampuan perusahaan untuk membayar kewajiban jangka panjangnya. Menurut penelitian Saputra (2003) dalam (Hayati, 2014) mengartikan bahwa tingkat hutang misalnya besar kecilnya tingkat penggunaan hutang jangka panjang dalam perusahaan. Hutang jangka panjang yang digunakan perusahaan semakin tinggi maka untuk membiayai aktiva perusahaan menunjukkan tingkat kestabilan perusahaan tersebut.

Hasil penelitian (Fitriana \& Fadhila, 2016) menunjukkan bahwa tingkat hutang yang diproksikan oleh rasio hutang memiliki pengaruh positif signifikan terhadap persistensi laba pada perusahaan property and real estate yang terdaftar di Bursa Efek Indonesia tahun 2010-2014. Sama hal yang dengan hasil penelitian lainnya yang menyatakan bahwa hubungan positif yang ditunjukkan oleh tingkat hutang terhadap persistensi laba berarti jika semakin tinggi tingkat hutang dalam suatu perusahaan, maka persistensi laba pada suatu perusahaan semakin tinggi pula. Besar kecilnya tingkat hutang akan mempengaruhi persistensi laba perusahaan dengan maksud untuk menengakkan kinerja yang baik untuk investor dan auditor. Tingkat hutang berpengaruh positif terhadap persistensi laba pada perusahaan pertambangan yang terdaftar di BEl. (Awaludin \& Darmansyah, 2018) Sedangkan hasil penelitian (Sulastri, 2014) menunjukkan bahwa tingkat hutang berpengaruh negatif namun tidak signifikan terhadap persistensi laba. Ada beberapa hasil penelitian yang sama yaitu Tingkat hutang secara parsial berpengaruh negatif terhadap persistensi laba. (Kasino \& Fachrurrozie, 2016). Sedangkan penelitian (Hayati, 2014) menyatakan bahwa tingkat hutang tidak 
berpengaruh signifikan terhadap persistensi laba pada perusahaan manufaktur yang terdaftar di Bursa Efek Indonesia periode 2009-2011 namun menunjukkan arah yang sama dengan hipotetsis yaitu positif. Ini artinya tingkat hutang yang meningkat memang menyebabkan peningkatan pada persistensi laba, tetapi tidak memberikan pengaruh yang cukup besar untuk proses pengambilan keputusan. Ada hasil penelitian yang menyatakan tidak berpengaruh yaitu penelitian (Nurochman \& Sholikhah, 2015) tingkat hutang yang dihitung dengan logaritma natural dari jumlah dana pihak ketiga dan ukuran perusahaan dan dihitung dengan menggunakan logaritma natural dari total aktiva tidak terbukti berpengaruh terhadap persitensi laba pada perusahaan perbankan yang terdaftar di Bursa Efek Indonesia (BEI).

Menurut (Rahmadhani et al., 2016) Volatilitas arus kas adalah tingkatan penyebaran distribusi atau indicator penyebaran arus kas perusahaan. Jika memiliki volatilitas kecil maka untuk menghitung persistensi laba dibutuhkan informasi arus kas yang stabil. Jika arus kas tidak tetap maka akan sulit untuk memprediksi arus kas di masa yang akan datang. Menurut pendapat (Sulastri, 2014) dalam penelitiannya menyimpulkan bahwa volatilitas arus kas adalah tidak tetapnya yang terjadi pada aliran kas dari satu periode ke periode lain. Volatilitas arus kas ialah derajat atau tingkatan bagian penyebaran arus kas atau indikator penyebaran pendistribusian arus kas perusahaan.

Menurut hasil penelitian (Asma, 2013) Aliran kas operasi (AKO) berpengaruh signifikan positif terhadap persistensi laba. Sama hal nya dengan hasil penelitian (Awaludin \& Darmansyah, 2018) dan (Hidayat \& Fauziyah, 2019) yang diperoleh hasil Arus Kas Operasi berpengaruh positif terhadap persistensi laba. Beda hal nya dengan hasil penelitian (Hayati, 2014) Dalam penelitian ini volatilitas arus kas operasi menunjukkan pengaruh signifikan negatif terhadap persistensi laba pada perusahaan manufaktur yang terdaftar di Bursa Efek Indonesia periode 2009-2011. Sehingga dapat dikatakan bahwa semakin fluktuasi meningkat yang akan terjadi pada arus kas operasi adalah persistensi laba perusahaan akan semakin rendah. Sedangkan hasil penelitian yang diperoleh oleh (Kasino \& Fachrurrozie, 2016) menunjukkan bahwa volatilitas arus kas secara parsial tidak berpengaruh terhadap persistensi laba.

Volatilitas penjualan adalah bagian penyebaran penjualan atau indeks penyebaran distribusi penjualan perusahaan. Volatilitas penjualan menunjukkan suatu volatilitas penyimpangan dan lingkungan operasi yang lebih besar menghasilkan pengukuran dan estimasi, dan berkorespondensi dengan kesalahan estimasi yang lebih besar dan kualitas akrual yang rendah. Yang disimpulkan oleh (Sulastri, 2014).

Volatilitas penjualan berpengaruh positif namun tidak signifikan terhadap persistensi laba adalah hasil penelitian yang dilakukan oleh (Sulastri, 2014) Volatilitas penjualan secara parsial berpengaruh positif terhadap persistensi laba.(Kasino \& Fachrurrozie, 2016). Volatilitas 
penjualan berpengaruh negatif signifikan terhadap persistensi laba yang berarti semakin tingginya fluktuasi penjualan maka kualitas laba akan rendah dan tidak mampu memprediksi laba pada periode yang akan datang dan sebaliknya, apabila volatilitas penjualan berfluktuasi rendah dan stabil bisa diprediksi untuk laba pada periode yang akan datang (Indra, 2014).

Kepemilikan institusional adalah salah satu alat pengukuran atau perhitungan dalam mekanisme tata kelola perusahaan yang baik. Kepemilikan institusional memiliki peran yang penting dalam mengawasi kinerja perusahaan yang dijelaskan oleh (Aisya, 2013).

Adapun penelitian yang dilakukan oleh (Aisya, 2013) Kepemilikan institusional memiliki pengaruh positif terhadap persistensi laba. Menurut penelitian yang dilakukan oleh (Sujana et al., 2017) sependapat dengan penelitian sebelumnya ia menyatakan bahwa Kepemilikan Institusional berpengaruh positif pada presistensi laba. Hal ini dipengaruhi oleh jumlah saham yang semakin meningkat dimiliki oleh pemilik saham institusi nilainya banyak, maka persistensi laba akan condong meningkat. Menurut penelitian yang dilakukan oleh (Dewata et al., 2016) beranggapan bahwa tidak memiliki pengaruh yang signifikan untuk kepemilikan institusional terhadap persistensi laba. Penelitian yang dilakukan (Khafid, 2012) sepakat bahwa Kepemilikan institusional tidak memiliki pengaruh secara signifikan terhadap persistensi laba. Dengan demikian, keberadaan para pemilik saham institusional tidak dapat memberikan pengaruh secara langsung terhadap persistensi laba.

\section{METODE}

Obyek yang digunakan dalam penelitian ini adalah perusahaan di sektor property, building, and real estate yang terdaftar di Bursa Efek Indonesia (BEI) periode 2013 - 2018. Data yang digunakan dalam penelitian ini adalah data kuantitatif yaitu data penelitian yang merupakan angka-angka dan analisis menggunakan statistik. (sugiono, 2017) dalam (Hidayat \& Fauziyah, 2019). Metode analisis yang digunakan dalam penelitian ini adalah metode analisis data kuantitatif dengan menggunakan Software Microsoft Excel 2016 untuk mengumpulkan datadata laporan keuangan perusahaan terkait dengan komponen-komponen yang digunakan untuk menghitung variabel dependen maupun variabel independen. Data yang dikumpulkan dalam penelitian ini adalah data panel, yaitu gabungan dari data cross section dan data time series Untuk mengolah data dalam penelitian ini digunakan program Eviews 10.0 sebagai alat untuk menguji data yang tersedia. Teknik yang digunakan dalam penelitian ini yaitu pengolahan atau penyajian data berupa analisis stastisik deskriptif dan analisis regresi data panel. Sedangkan sumber yang digunakan dalam penelitian ini adalah data sekunder. www.idx.co.id. Populasi dalam penelitian ini adalah perusahaan manufaktur yang terdaftar di Bursa Efek Indonesia (BEI) pada tahun 2013 - 2018. Dalam sektor Real Estate dan Properti banyak terdapat perusahaan yang pada 
dasarnya masil berkembang. Oleh karena itu, pada sektor ini dilakukan penelitian. Metode pengambilan sampel yang digunakan adalah purposive sampling. Kriteria-kriteria yang digunakan untuk mengambil sampel dalam penelitian ini sehingga sampel dapat terpilih adalah sebagai berikut:

a. Perusahaan yang bergerak dalam sector property dan Real Estate yang terdaftar berturut-turut di BEl tahun 2013-2018 dan masih melakukan kegiatan operasinya sampai dengan Desember 2018.

b. Perusahaan yang mempublikasikan laporan keuangan disajikan dalam mata uang rupiah yang telah diaudit periode 31 Desember secara konsisten selama periode pengamatan serta memiliki data keuangan yang lengkap sesuai dengan yang dibutuhkan dalam penelitian.

c. Perusahaan yang tidak menderita kerugian baik dalam laporan keuangan komersial ataupun laporan keuangan pajak.

Tabel 1. Seleksi Sampel Penelitian

\begin{tabular}{|c|l|c|}
\hline No. & \multicolumn{1}{|c|}{ Kriteria Sample } & Jumlah \\
\hline 1 & $\begin{array}{l}\text { Perusahaan Sektor Properti, Real estate, Building contruction yang } \\
\text { terdaftar di BEI periode 2013-2018 }\end{array}$ & 73 \\
\hline 2 & $\begin{array}{l}\text { Perusahaan yang tidak mempublikasikan laporan keuangan } \\
\text { tahunan secara berturut-turut untuk Periode 2013-2018 }\end{array}$ & 13 \\
\hline 3 & $\begin{array}{l}\text { Perusahaan dari Sektor Sektor Properti, Real estate, Building } \\
\text { contruction yang mengalami kerugian selama periode penelitian }\end{array}$ & 4 \\
\hline 5 & $\begin{array}{l}\text { Perusahaan sektor Sektor Properti, Real estate, Building } \\
\text { contruction yang tidak mengungkapkan data yang diperlukan } \\
\text { dalam penelitian secara lengkap periode 2017-2018 }\end{array}$ & 44 \\
\hline 5 & $\begin{array}{l}\text { Perusahaan yang tercatat di Sektor Sektor Properti, Real estate, } \\
\text { Building contruction yang delisting }\end{array}$ & $\begin{array}{l}\text { Perusahaan Sektor Sektor Properti, Real estate, Building } \\
\text { contruction yang menyajikan Laporan Keuangan yang tidak } \\
\text { dipublikasikan }\end{array}$ \\
\hline & $\begin{array}{l}\text { Total sampel perusahaan Sektor Sektor Properti, Real estate, } \\
\text { Building contruction yang memuat data yang dibutuhkan dalam } \\
\text { penelitian pada tahun 2013-2018 }\end{array}$ & $\mathbf{7}$ \\
\hline Jumlah Observasi selama 6 tahun pengamatan (6 X 7) & $\mathbf{4 2}$ \\
\hline
\end{tabular}

Penelitian ini menggunakan dua jenis variabel yaitu variabel dependen yaitu Persistensi Laba, variabel independen yaitu Book tax Differences, 
Arus Kas Operasi, Tingkat Hutang, Volatilitas Penjualan dan Ukuran Perusahaan.

\section{a. Persistensi Laba}

Menurut (Djamaludin, 2008) dalam (Septavita, 2016) Persistensi laba adalah perbaikan dalam laba akuntansi yang diharapkan di mendatang (expected future earnings) yang bersangkutan dengan laba akuntansi tahun berjalan. Persistensi laba dihitung melalui laba sebelum pajak tahun mendatang. Laba sebelum pajak tahun mendatang merupakan selisih antara pendapatan dan beban pada tahun mendatang sebelum dikurangi dengan beban pajak yang dibagi dengan rata - rata jumlah aset (Septavita, 2016).

$$
\begin{gathered}
\text { Persistensi Laba }=\frac{\text { laba sebelum pajak } t+1}{\text { rata }- \text { rata total aset }} \\
\text { (sumber : Hidayat \& Fauziyah, 2019) }
\end{gathered}
$$

\section{b. Book Tax Differences $\left(\mathrm{X}_{1}\right)$}

Menurut (Lailatul et al., 2017) Selisih laba akuntansi dan laba pajak terjadi karena adanya perbedaan peraturan yang berbeda antara standar akuntansi dengan peraturan perpajakan. Sebagai mana hal tersebut dapat menyebabkan transaksi yang sama dicatat dengan nilai yang berbeda akibat adanya perencanaan pajak.

$$
\begin{aligned}
& B T D=\frac{\text { penghasilan Kena Pajak }- \text { Laba }}{\text { rata - rata aset }} \\
& \text { (Sumber : Hidayat \& Fauziyah, 2019) }
\end{aligned}
$$

\section{c. Tingkat Hutang $\left(\mathbf{X}_{\mathbf{2}}\right)$}

Menurut (Septavita, 2016) Tingkat hutang merupakan hal penting dalam penentuan struktur modal perusahaan. Tingkat hutang misalnya penggunaan dana beserta biaya tetap. Adanya pendapat lain yaitu menurut Weston and Copeland (2009) dalam (Septavita, 2016) yang memaparkan bahwa tingkat hutang atau sering disebut leverage factor ialah rasio yang berasal nilai buku keseluruhan hutang terhadap total aktiva. Perhitungan tingkat hutang ini berasal dari total hutang dibagi dengan total aset.

$$
\text { Tingkat Hutang }=\frac{\text { Total Hutang }}{\text { Total aset }}
$$

(Sumber : Hidayat \& Fauziyah, 2019)

\section{d. Arus Kas Operasi $\left(\mathrm{X}_{3}\right)$}

Menurut (Septavita, 2016) Arus Kas Operasi Penerimaan dan pembayaran kas selama satu periode diklasifikasikan menjadi tiga aktifitas yang berbeda yaitu aktivitas operasi, investasi dan pendanaan. Jumlah 
arus kas operasi misalnya arus kas yang diperoleh dari kegiatan atau aktivitas operasi yang merupakan indikator untuk menentukan apakah operasi perusahaan dapat menghasilkan arus kas yang cukup atau tidak untuk melunasi pinjaman, membayar dividen dan melakukan investasi baru. Semakin banyaknya aliran kas operasi maka persistensi laba akan meningkat. Aliran kas sangat berguna ungtuk mengecek persistensi laba.

$$
A K O=\frac{\text { Arus Kas Operasi }-P p h}{\text { Total Aset }}
$$

\section{e. Volatilitas Penjulan $\left(\mathbf{X}_{4}\right)$}

(Sumber : Sukman, 2017)

Menurut (Rahmadhani et al., 2016) Volatilitas penjualan adalah standar deviasi penjualan dibagi dengan total aktiva.

\section{f. Kepemilikan Institusional $\left(\mathbf{X}_{5}\right)$}

$$
\text { Volatilitas Penjualan }=\frac{\text { Penjualan }}{\text { Total aset }}
$$

(Sumber :Indra, 2014)

Menurut Khurana dan Moser dalam Annisa dan Kurniasih (2012) dalam penelitian (Aisya, 2013) menyatakan bahwa kepemilikan sebagian saham oleh perusahaan ini dapat dijadikan sebagai kontrol dalam pelaporan keuangan.

$$
\begin{aligned}
& \text { Kep. Institusional }=\frac{\text { Jumlah saham institusi }}{\text { Total saham beredar }} \\
& \text { ( Sumber : Nurochman \& Sholikhah, 2015) }
\end{aligned}
$$

\section{HASIL}

\section{a. Pengaruh Book Tax Differences (BTD) terhadap persistensi laba}

Book Tax Differences menunjukkan koefisien negatif sebesar 1.080840 dengan tingkat signifikan $0.0000<\alpha=0,05$. Karena tingkat signifikan lebih besar dari $\alpha=0,05$ maka $\mathrm{H} 1$ diterima sehingga kesimpulannya Book Tax Differences adalah berpengaruh negatif terhadap Persistensi Laba.

Hasil Penelitian ini didukung dengan penelitian yang dilakukan oleh (Asma, 2013) dan (Zdulhiyanov, 2015) menyatakan perbedaan laba akuntansi dengan laba fiskal berpengaruh signifikan negatif terhadap persistensi laba.

\section{b. Pengaruh Tingkat Hutang terhadap Persistensi Laba}

Tingkat Hutang menunjukkan koefisien negatif sebesar -0.000180 dengan tingkat signifikan $0.9942>\alpha=0,05$. Karena tingkat signifikan lebih besar dari $\alpha=0,05$ maka $\mathrm{H} 2$ ditolak sehingga kesimpulannya Tingkat Hutang adalah tidak berpengaruh terhadap Persistensi Laba.

Hasil Penelitian ini didukung dengan penelitian yang dilakukan oleh (Hayati, 2014) menyatakan bahwa tingkat hutang tidak berpengaruh signifikan terhadap persistensi laba pada perusahaan manufaktur yang 
terdaftar di Bursa Efek Indonesia periode 2009-2011 namun menunjukkan arah yang sama dengan hipotetsis yaitu positif. Ini artinya tingkat hutang yang meningkat memang menyebabkan peningkatan pada persistensi laba, tetapi tidak memberikan pengaruh yang cukup besar untuk proses pengambilan keputusan. Ada hasil penelitian yang menyatakan tidak berpengaruh yaitu penelitian (Nurochman \& Sholikhah, 2015) tingkat hutang yang dihitung dengan logaritma natural dari jumlah dana pihak ketiga dan ukuran perusahaan dan dihitung dengan menggunakan logaritma natural dari total aktiva tidak terbukti berpengaruh terhadap persitensi laba pada perusahaan perbankan yang terdaftar di Bursa Efek Indonesia (BEI).

Namun penelitian ini tidak sejalan dengan penelitian yang dilakukan oleh (Fitriana \& Fadhila, 2016) yang menjelaskan bahwa tingkat hutang yang diproksikan oleh rasio hutang memiliki pengaruh positif terhadap persistensi laba pada perusahaan property dan perumahan yang terdaftar di Bursa Efek Indonesia periode 2010-2014. Sama hal yang dengan hasil penelitian lainnya yang menyatakan bahwa hubungan positif yang ditunjukkan oleh tingkat hutang terhadap persistensi laba berarti jika semakin tinggi tingkat hutang dalam suatu perusahaan, maka persistensi laba pada suatu perusahaan semakin tinggi pula. Besar kecilnya tingkat hutang akan memberikan pengaruh terhadap persistensi laba perusahaan bertujuan untuk menengakkan kinerja yang baik untuk investor dan auditor. Tingkat hutang berpengaruh positif terhadap persistensi laba pada perusahaan pertambangan yang terdaftar di BEl. (Awaludin \& Darmansyah, 2018).

\section{c. Pengaruh AKO (Arus Kas Operasi) terhadap persistensi Laba}

Arus Kas Operasi menunjukkan koefisien positif sebesar 0.081140 dengan tingkat signifikan $0.4040>\alpha=0,05$. Karena tingkat signifikan lebih besar dari $\alpha=0,05$ maka H3 ditolak sehingga kesimpulannya Arus Kas Operasi adalah tidak berpengaruh terhadap Persistensi Laba.

Hasil Penelitian ini didukung dengan penelitian yang dilakukan oleh (Kasino \& Fachrurrozie, 2016) menunjukkan bahwa volatilitas arus kas secara parsial tidak berpengaruh terhadap persistensi laba.

Namun penelitian ini tidak sejalan dengan Hasil penelitian terdahulu menurut (Asma, 2013) Aliran kas operasi (AKO) berpengaruh signifikan positif terhadap persistensi laba. Penelitian yang sama ditunjukkan oleh (Indra, 2014) yang menunjukkan bahwa Volatilitas arus kas berpengaruh signifikan positif terhadap persistensi laba yang berarti jika fluktuasi arus kas rendah maka mengindikasikan rendahnya ketidakjelasan yang terjadi dalam lingkungan operasi sehingga menyebabkan kualitas laba menjadi rendah dan tidak untuk memprediksi laba pada periode masa mendatang. Arus kas operasi berpengaruh positif pada persistensi laba. (Dewi \& Putri, 2015). Adapun penelitian terdahulu lainnya yaitu berdasarkan hasil penelitian (Awaludin \& Darmansyah, 2018) arus kas operasional berpengaruh signifikan positif terhadap persistensi laba pada perusahaan 
pertambangan yang terdaftar di BEl. Dan penelitian yang dilakukan oleh (Hidayat \& Fauziyah, 2019) yang diperoleh hasil Arus Kas Operasi berpengaruh positif terhadap persistensi laba. Hal tersebut merujuk pada arus kas operasi misalnya faktor yang mempengaruhi tinggi rendahnya persistensi laba perusahaan. Jika arus kas operasi (AKO) sebuah perusahaan tinggi maka akan persistensi labanya juga akan tinggi.

\section{d. Pengaruh Volatilitas Penjualan terhadap Persistensi Laba}

Volatilitas Penjualan menunjukkan koefisien negatif sebesar 0.046549 dengan tingkat signifikan $0.1844>\alpha=0,05$. Karena tingkat signifikan lebih besar dari $\alpha=0,05$ maka $\mathrm{H} 4$ ditolak sehingga kesimpulannya Volatilitas Penjualan adalah tidak berpengaruh terhadap Persistensi Laba.

Namun penelitian ini tidak sejalan dengan Hasil penelitian terdahulu menurut Volatilitas penjualan berpengaruh positif namun tidak signifikan terhadap persistensi laba adalah hasil penelitian yang dilakukan oleh (Sulastri, 2014) Volatilitas penjualan secara parsial berpengaruh positif terhadap persistensi laba.(Kasino \& Fachrurrozie, 2016)

\section{e. Pengaruh Kepemilikan Institusional terhadap Persistensi Laba}

Kepemilikan Institusional menunjukkan koefisien positif sebesar 0.036108 dengan tingkat signifikan $0.0004<\alpha=0,05$. Karena tingkat signifikan lebih besar dari $\alpha=0,05$ maka $\mathrm{H} 5$ diterima sehingga kesimpulannya Kepemilikan Institusional adalah berpengaruh positif terhadap Persistensi Laba.

Hasil Penelitian ini didukung dengan penelitian yang dilakukan oleh (Sujana et al., 2017) menyatakan Kepemilikan Institusional berpengaruh positif pada persistensi laba. Sebagaimana dijelaskan bahwa semakin banyak jumlah saham yang dimiliki pemegang saham institusi, maka persistensi laba akan cenderung meningkat. Sama hal nya dengan penelitian yang dilakukan oleh (Aisya, 2013) Kepemilikan institusional memiliki pengaruh terhadap persistensi laba dengan hubungan positif.

\section{KESIMPULAN}

Dapat dilihat dari hasil penelitian yang telah dilakukan oleh penulis, sehingga dapat disimpulkan bahwa :

1. Book Tax Differences (BTD) memiliki pengaruh negatif terhadap persistensi laba

2. Tingkat Hutang tidak memiliki pengaruh terhadap persistensi laba

3. Arus Kas Operasi (AKO) tidak memiliki pengaruh terhadap persistensi laba

4. Volatilitas Penjualan tidak memiliki pengaruh terhadap persistensi laba

5. Kepemilikan Institusional memiliki pengaruh positif terhadap persisitensi laba. 
Penulis memiliki beberapa hal yang disarankan untuk penelitian selanjutnya adalah sebagai berikut :

1. Semoga penelitian selanjutnya dapat lebih baik lagi dalam menyajikan penelitiannya.

2. Semoga penelitian selanjutnya dapat menambah sektor perusahaan.

3. Semoga penelitian selanjutnya dapat memiliki variabel independen yang berpengaruh terhadap variabel dependen yang belum ada pada penelitian ini.

\section{DAFTAR PUSTAKA}

Aisya, E. N. (2013). Pengaruh Kepemilikan Institusional, Komisaris Independen, Kualitas Audit, Komite Audit Dan Book Tax Difference Terhadap Persistensi Laba (Studi Kasus Pada Perusahaan Yang Terdaftar Di Indeks Lq45 Periode 2012-2015). Journal of Chemical Information and Modeling, 53(9), 1689-1699. https://doi.org/10.1017/CBO9781107415324.004

Annisa, R., \& Kurniasih, L. (2017). Analisis Pengaruh Perbedaan Laba Akuntansi dengan Laba Fiskal dan Komponen Laba terhadap Persistensi Laba. Jurnal Akuntansi Dan Bisnis, 17(1), 61. https://doi.org/10.20961/jab.v17i1.221

Asma, T. N. (2013). Pengaruh aliran kas dan perbedaan antara laba akuntansi dengan laba fiskal terhadap persistensi laba. Jurnal Akuntansi Universitas Negeri Padang, 1-16.

Awaludin, W., \& Darmansyah. (2018). Peran Komite Audit sebagai Pemoderasi Atas Determinan Persistensi Laba Perusahaan Pertambangan. 230-244.

Cavenett. (2013). Grand Theory. Journal of Chemical Information and Modeling, 53(9), 1689-1699. https://doi.org/10.1017/CBO9781107415324.004

Dewata, E.-, Sari, Y., \& Fithri, E. J. (2016). Kepemilikan Manajerial dan Institusional sebagai Determinan Struktur Modal dan Persistensi Laba. Journal of Research and Applications: Accounting and Management, 1(3), 223. https://doi.org/10.18382/jraam.v1i3.59

Dewi, N., \& Putri, I. (2015). Pengaruh Book-Tax Difference, Arus Kas Operasi, Arus Kas Akrual, Dan Ukuran Perusahaan Pada Persistensi Laba. E-Jurnal Akuntansi, 10(1), 244-260.

Eksandy, Arry. 2018. Metode Penelitian Akuntansi dan Manajemen. Tangerang: FEB UMT.

Fitriana, N., \& Fadhila, W. (2016). Pengaruh Tingkat Hutang dan Arus Kas Akrual terhadap Persistensi Laba. Jurnal IImiah Mahasiswa Ekonomi Akuntansi, 1(1), 258-272.

Gusnita, Y., \& Taqwa, S. (2019). Pengaruh Keandalan Akrual, Tingkat Utang dan Ukuran Perusahaan Terhadap Persistensi Laba (Studi Empiris pada Perusahaan Sektor Keuangan Yang Terdaftar di Bursa Efek Indonesia Tahun 2014-2017). Jurnal Eksplorasi Akuntansi, 1(3), 
1131-1148.

Hayati, O. S. (2014). Pengaruh Volatilitas Arus Kas dan Tingkat Hutang Terhadap Persistensi Laba. E-Journal UNP, 2(2), 1-29.

Hidayat, I., \& Fauziyah, S. (2019). PENGARUH BOOK TAX DIFFERENCES, ARUS KAS OPERASI, TINGKAT HUTANG DAN UKURAN PERUSAHAAN TERHADAP PERSISTENSI LABA. Journal of Chemical Information and Modeling, 53(9), 1689-1699. https://doi.org/10.1017/CBO9781107415324.004

Indra, C. (2014). PENGARUH VOLATILITAS ARUS KAS, BESARAN AKRUAL, VOLATILITAS PENJUALAN TERHADAP PERSISTENSI $\angle A B A$. May.

Kasino, D., \& Fachrurrozie. (2016). Determinan Persistensi Laba Pada Perusahaan Manufaktur Yang Terdaftar Di Bei. Accounting Analysis Journal, 5(1), 1-8. https://doi.org/10.15294/aaj.v5i1.9760

Khafid, M. (2012). Pengaruh Tata Kelola Perusahaan (Corporate Governance) Dan Struktur Kepemilikan Terhadap Persistensi Laba. Jurnal Dinamika Akuntansi, 4(2), 139-148. https://doi.org/10.15294/jda.v4i2.2172

Kritik, P. D. A. N., Pengajar, S., Ekonomi, F., \& Diponegoro, U. (2016). TEORI AKUNTANSI POSITIF Oleh. May.

Lailatul, E., Ulum, I., \& Harventy, G. (2017). Pengaruh Book Tax Differences dan Struktur Kepemilikan Saham terhadap Persistensi Laba. Jurnal Akuntansi, 5(1), 673-682.

Nurochman, A., \& Sholikhah, B. (2015). Pengaruh Good Corporate Governance, Tingkat Hutang Dan Ukuran Perusahaan Terhadap Persistensi Laba. Accounting Analysis Journal, 4(4), 1-9. https://doi.org/10.15294/aaj.v4i4.9111

Persada, A. E., \& Martani, D. (2010). Analisis Faktor Yang Mempengaruhi Book Tax Gap Dan Pengaruhnya Terhadap Persistensi Laba. Jurnal Akuntansi Dan Keuangan Indonesia, 7(2), 205-221. https://doi.org/10.21002/jaki.2010.12

Rahmadhani, A., Zulbahridar, Z., \& Hariadi, H. (2016). PENGARUH BOOK-TAX DIFFERENCES, VOLATILITAS ARUS KAS, VOLATILITAS PENJUALAN, BESARAN AKRUAL, DAN TINGKAT UTANG TERHADAP PERSISTENSI LABA (Studi Empiris pada Perusahaan Aneka Industri yang terdaftar di BEI tahun 2010-2014). Jurnal Online Mahasiswa Fakultas Ekonomi Universitas Riau, 3(1), 2163-2176.

Septavita, N. (2016). PENGARUH BOOK TAX DIFFERENCES, ARUS KAS OPERASI, TINGKAT HUTANG, DAN UKURAN PERUSAHAAN TERHADAP PERSISTENSI LABA. Journal of Chemical Information and $\quad$ Modeling, 6(2), 1689-1699. https://doi.org/10.1017/CBO9781107415324.004

Sujana, I. M., Yasa, G. W., \& Badera, I. D. N. (2017). Pengaruh Komite Audit Dan Kepemilikan Institusional. 12, 4311-4338.

Sukman. (2017). Pengaruh Arus Kas Operasi, Tingkat Hutang, Dan 
Ukuran Perusahaan Terhadap Persistensi Laba Dengan Book Tax Differences Sebagai Variabel Moderating. Skripsi.

Sulastri, D. A. (2014). Pengaruh Volatilitas Arus Kas, Volatilitas Penjualan, Besaran Akrual, dan Tingkat Hutang terhadap Persistensi Laba. EJournal UNP, 2(2), 1-29.

Zdulhiyanov, M. (2015). Pengaruh Boox Tax Differences terhadap

Persistensi Laba. Ejournal UNP, 3(2), 443-451.

https://www.idx.co.id/ diakses pada tanggal 10 Maret 2020.

https://industri.kontan.co.id/ diakses pada tanggal 12 Maret 2020 